\title{
FGD4 wt Allele
}

National Cancer Institute

\section{Source}

National Cancer Institute. FGD4 wt Allele. NCI Thesaurus. Code C104380.

Human FGD4 wild-type allele is located in the vicinity of $12 \mathrm{p} 11.21$ and is approximately $246 \mathrm{~kb}$ in length. This allele, which encodes FYVE, RhoGEF and PH domain-containing protein 4, is involved in regulation of the actin cytoskeleton and cell shape. Mutations in this gene are associated with Charcot-Marie-Tooth disease type 4H (CMT4H). 